\title{
Effects of Graphene Oxide-Gold Nanoparticles Nanocomposite on Highly Sensitive Foot-and-Mouth Disease Virus Detection
}

\author{
Jong-Won Kim ${ }^{1,2}$, Myeongkun Kim ${ }^{1,2}$, Kyung Kwan Lee ${ }^{1,2,3}$, Kwang Hyo Chung ${ }^{2}$ and \\ Chang-Soo Lee ${ }^{1,2,4, *}$ \\ 1 Bionanotechnology Research Center, Korea Research Institute of Bioscience \& Biotechnology (KRIBB) 125 \\ Gwahak-ro, Yuseong-gu, Daejeon 34141, Korea; kimjw@kribb.re.kr (J.-W.K.); kmkun8510@kribb.re.kr (M.K.); \\ lkk@kribb.re.kr (K.K.L.) \\ 2 Dignostics Platform Research Section, Electronics and Telecommunications Research Institute (ETRI) 218 \\ Gajeong-ro, Yuseong-gu, Daejeon 34129, Korea; hyo@etri.re.kr \\ 3 Department of Life and Nanopharmaceutical Science, College of Pharmacy, Kyung Hee University, \\ Seoul 02447, Korea \\ 4 Department of Biotechnology, University of Science \& Technology (UST), Daejeon 34113, Korea \\ * Correspondence: cslee@kribb.re.kr
}

Received: 2 September 2020; Accepted: 23 September 2020; Published: 25 September 2020

\begin{abstract}
The polymerase chain reaction (PCR) has become a powerful molecular diagnostic technique over the past few decades, but remains somewhat impaired due to low specificity, poor sensitivity, and false positive results. Metal and carbon nanomaterials, quantum dots, and metal oxides, can improve the quality and productivity of PCR assays. Here, we describe the ability of PCR assisted with nanomaterials (nano-PCR) comprising a nanocomposite of graphene oxide (GO) and gold nanoparticles (AuNPs) for sensitive detection of the foot-and-mouth disease virus (FMDV). Graphene oxide and AuNPs have been widely applied as biomedical materials for diagnosis, therapy, and drug delivery due to their unique chemical and physical properties. Foot-and-mouth disease (FMD) is highly contagious and fatal for cloven-hoofed animals including pigs, and it can thus seriously damage the swine industry. Therefore, a highly sensitive, specific, and practical method is needed to detect FMDV. The detection limit of real-time PCR improved by 1000 fold when assisted by GO-AuNPs. We also designed a system of detecting serotypes in a single assay based on melting temperatures. Our sensitive and specific nano-PCR system can be applied to diagnose early FMDV infection, and thus may prove to be useful for clinical and biomedical applications.
\end{abstract}

Keywords: polymerase chain reaction; foot-and-mouth disease virus; graphene oxide; gold nanoparticle

\section{Introduction}

Foot-and-mouth disease (FMD) is a highly contagious and fatal disease of wild and domestic cloven-hoofed animals such as cattle, sheep, goat, and swine. It is caused by infection with the foot-and-mouth disease virus (FMDV). This RNA virus belongs to the genus Aphthovirus of the family of a Picornaviridae [1], and has been classified as serotypes O, A, C, SAT 1, SAT 2, SAT 3, and Asia 1 [2]. Since it can disseminate over long distances, FMD can severely restrict international trade in animals and related materials, and trigger massive economic damage because FMDV is highly infectious and can cause acute epidemics in FMD-free areas [3]. Various in vitro diagnostic methods such as enzyme-linked immunosorbent assays (ELISA) [4], hybridization assays [5], and polymerase chain reaction (PCR) [6-13], have been developed to detect various viruses. Molecular detection 
of FMDV using PCR and loop-mediated isothermal amplification (LAMP) is considered highly sensitive [14-16]. The sensitivity of PCR is high due to amplification of the target DNA and it a powerful molecular diagnostic technique. However, the utility of PCR is limited due to low specificity and efficiency due to time-consuming and temperature-dependent denaturation, annealing, and elongation steps that frequently generate false positive results. Thus, a highly sensitive, specific, and rapid method of detecting FMDV is required. Nanomaterial-assisted PCR (nano-PCR) has recently been developed to overcome these limitations and improve efficiency over conventional PCR [17-19]. Nanomaterials, including gold and magnetic nanoparticles, titanium oxide, quantum dots, and carbon-based materials have been used to develop PCR assays with outstanding sensitivity, specificity, and efficiency. These nanomaterials are thought to improve PCR efficiency and specificity via increased thermal conductivity and interaction with PCR reagents [20-23]. In nano-PCR, enhanced efficiency within shorter overall thermal cycling periods has been observed compared with conventional PCR due to simple addition of gold nanoparticles to PCR reaction mixtures [24-27].

We developed a nano-PCR system for the sensitive and specific detection of FMDV by enhancing PCR with graphene oxide-gold nanoparticles nanocomposite (GO-AuNPs) that supported DNA amplification and improved PCR efficiency by interacting with PCR reagents. We designed specific serotype $\mathrm{O}_{-}, \mathrm{A}_{-}$, and pan-type specific primers for real-time PCR with GO-AuNPs to distinguish between serotypes that have emerged in South Korea over several decades. The sensitivity of our nano-PCR system was 1000-fold higher than that of conventional PCR, and the enhanced efficiency could be precisely controlled by changing the GO-AuNPs content. This remarkable amplification ability would be useful for many critical circumstances, such as diagnosis of the early stages of various infectious diseases.

\section{Materials and Methods}

\subsection{Materials}

Graphene oxide in solution was purchased from Graphene Supermarket (Calverton, NY, USA). Gold (III) chloride trihydrate $\left(\mathrm{HAuCl}_{4} \cdot 3 \mathrm{H}_{2} \mathrm{O}\right)$ and trisodium citrate $\left(\mathrm{Na}_{3} \mathrm{C}_{6} \mathrm{H}_{5} \mathrm{O}_{7}\right)$ were from Sigma-Aldrich (St. Louis, MO, USA). The nPfu-forte polymerase was obtained from Enzymonics (Daejeon, Korea). Primers and FMDV genes were synthesized by Bioneer (Daejeon, Korea) and Integrated DNA technologies (IDT), respectively. SYBR Green I was purchased from Lonza (Rockland, ME, USA).

\subsection{Preparation of GO-AuNPs Nanocomposite}

The GO-AuNPs were prepared through a modification of the in situ reduction method $[28,29]$. Briefly, $5 \mathrm{~mL}$ of graphene oxide $(1.5 \mathrm{mg} / \mathrm{mL})$ was sonicated for $5 \mathrm{~min}$; then, $\mathrm{HAuCl}_{4} \cdot 3 \mathrm{H}_{2} \mathrm{O}(0.1 \mathrm{mg} / \mathrm{mL}$, $100 \mathrm{~mL}$ ) was added, and the mixture was incubated under magnetic stirring for $30 \mathrm{~min}$ to allow gold ions to adsorb onto graphene oxide surfaces. The solution was heated at $90^{\circ} \mathrm{C}$, and then the reducing agent, sodium citrate $(0.035 \mathrm{~g} / \mathrm{mL}, 1 \mathrm{~mL})$, was added. The reaction was continued for $1 \mathrm{~h}$, and the resultant solution was cooled to room temperature and washed three times by centrifugation at $3940 \times g$ with distilled water to remove free gold nanoparticles.

\subsection{Characterization of GO-AuNPs}

The GO-AuNPs were characterized by UV/vis spectroscopy, transmission electron microscopy (TEM), and zeta potential. The optical spectrum of GO-AuNPs was determined using a UV/Vis spectrophotometer (Optizen pop, Mecasys, South Korea). Morphology and zeta potentials were assessed using a Talos F200X field-emission transmission electron microscope (TEM) (FEI Co., Hillsboro, OR, USA) at $200 \mathrm{kV}$, and dynamic light scattering (DLS; Zetasizer Nano ZS, Malvern Instruments, Malvern, UK), respectively. 


\subsection{Construction of FMDV Gene Plasmid}

Serotype O- and A-type FMDV genes that originated from O-type (O/Andong/KOR/2010) and A-type (A/Pocheon/001/KOR/2010) strains were designed based on part of the RNA-dependent RNA polymerase sequence. The synthesized O- and A-type genes were cloned into pET-21a plasmids (Novagen, Inc., Madison, WI, USA). The constructed plasmids were transformed into the Escherichia coli (E. coli) host strain DH5 $\alpha$ (RBC Bioscience Corp., New Taipei City, Taiwan). A single colony was selected and incubated in Luria-Bertani (LB) medium containing ampicillin $(100 \mu \mathrm{g} / \mathrm{mL})$ at $37^{\circ} \mathrm{C}$ overnight. Cultured cells were harvested, and plasmids were prepared using extraction kits (Bioneer, Daejeon, Korea).

\subsection{Real-Time PCR}

We designed serotype O-, A-, and pan-type primers to investigate the performance of GO-AuNPs in real-time PCR (Table 1). The PCR mixture (total volume, $20 \mu \mathrm{L}$ ) consisted of 1X nPfu-forte buffer containing $200 \mu \mathrm{M}$ each of dNTP, 1X SYBR Green I dye, $250 \mathrm{nM}$ of each primer, $0.5 \mathrm{mg} / \mathrm{mL}$ bovine serum albumin (BSA), $0.5 \mathrm{U}$ nPfu-forte polymerase, DNA templates, and optimal concentrations of AuNPs, GO, and GO-AuNPs. All real-time PCR reactions were performed on the CFX96 real-time PCR system (Bio-Rad Laboratories, Inc., Hercules CA, USA) and DNA was amplified using 40 cycles of denaturation at $95^{\circ} \mathrm{C}$ for $10 \mathrm{~s}$, annealing at $60{ }^{\circ} \mathrm{C}$ for $5 \mathrm{~s}$, and extension at $72{ }^{\circ} \mathrm{C}$ for $20 \mathrm{~s}$. We analyzed melting curves as fluorescent signals over a temperature range of $65^{\circ} \mathrm{C}$ to $95{ }^{\circ} \mathrm{C}$, that increased in $0.5^{\circ} \mathrm{C}$ increments for $5 \mathrm{~s}$ after DNA amplification. The results were analyzed using CFX Maestro software (CFX96; Bio-Rad Laboratories, Inc., Hercules, CA, USA). Amplicons were loaded onto 2\% agarose gels with a nucleic acid stain and resolved by electrophoresis at $100 \mathrm{~V}$ for $30 \mathrm{~min}$. Bands were visualized using a UV lamp at a wavelength of $254 \mathrm{~nm}$.

Table 1. Primer sequences used in this study.

\begin{tabular}{ccc}
\hline Type of FMDV Gene & Amplicon Size (bp) & Sequence \\
\hline O-type & 117 & $\begin{array}{c}\text { Forward: GCCTTGGAACTCATAGAGAAAAG } \\
\text { Reverse: CAAAACATCGACGATGCGC }\end{array}$ \\
\hline A-type & 208 & $\begin{array}{c}\text { Forward: GTTTGCACGGTGTGCTGG } \\
\text { Reverse: CTTTTCTCCATGAGCTCTAGAGC }\end{array}$ \\
\hline Pan-type & 225 & $\begin{array}{c}\text { Forward: TGAGGAGGTGTTTCGCACA } \\
\text { Reverse: GTGTAAGTGTCCAGCTCAACTC }\end{array}$ \\
\hline
\end{tabular}

\section{Results}

\subsection{Characterization of GO-AuNPs Nanocomposite}

We evaluated the detection efficiency of FMDV by PCR using AuNPs, GO and GO-AuNPs, respectively. The GO-AuNPs were synthesized using a modification of in situ reduction $[28,29]$, comprising seed-mediated growth on GO sheets, with three sizes of citrate-capped AuNPs ( 10, 15, and $28 \mathrm{~nm}$ ). Among them, GO-AuNPs with 15-nm AuNPs on GO sheets show the most efficient PCR performance (data not shown), thus, demonstrating that the size of AuNPs has a decisive effect on nano-PCR.

We characterized the GO-AuNPs using UV/Vis spectroscopy, zeta potentials, and TEM (Figure 1). The optical properties of the nanomaterials were verified based on UV/Vis absorption spectra. Figure 1a shows an absorption peak of AuNPs and GO-AuNPs at $520 \mathrm{~nm}$, which is typical of the localized surface plasmon resonance (LSPR) spectrum. The spectrum of GO and GO-AuNPs peaked at $288 \mathrm{~nm}$, thereby indicating $\pi-\pi^{*}$ transitions for the $C=C$ bonds and $n-\pi^{*}$ transitions for the $C=O$ bonds of $G O[28,30]$. These results confirmed that GO-AuNPs had the optical characteristics of both AuNPs and GO, thereby implying successful absorption of AuNPs onto the surface of the GO sheets. We next evaluated the zeta 
potentials of GO-AuNPs to determine surface charges on the nanomaterials (Figure 1b). The estimated zeta potentials of AuNPs, GO, and GO-AuNPs were $-15.43 \pm 2.73,-41.87 \pm 0.87$, and $-30.53 \pm 1.36 \mathrm{mV}$, respectively. The average zeta potential of GO-AuNPs was less negatively charged $(-30.53 \pm 1.36 \mathrm{mV})$ than GO $(-41.87 \pm 0.87 \mathrm{mV})$, due to the coverage of AuNPs prepared from in situ reduction on the GO surface [31]. The size, shape, and distribution of GO-AuNPs examined by TEM showed that the spherical AuNPs were randomly distributed and localized on the surface of GO sheets with a diameter of $15.6 \pm 1.3 \mathrm{~nm}$, and morphological deformation was not evident (Figure 1c). These results showed that GO could serve as a supporting substrate for the hybrid material with characteristics of both GO and AuNPs. They also confirmed that GO could prevent self-aggregation by acting as a building block, while preserving good water dispersibility.
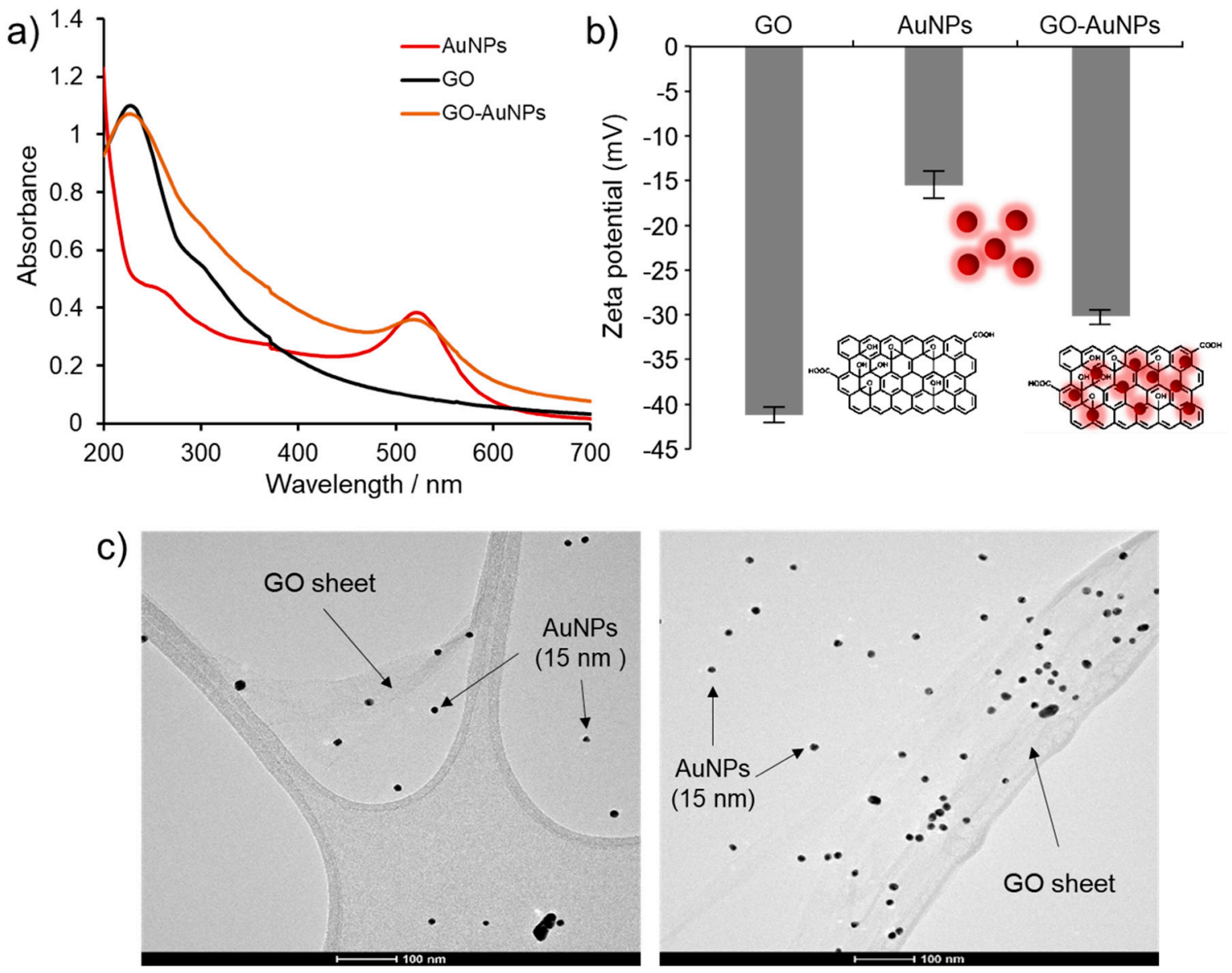

Figure 1. Characterization of GO-AuNPs. UV/Vis absorption spectra (a), zeta potentials (b) of AuNPs, GO, and GO-AuNPs, and TEM image (c) of GO-AuNPs.

\subsection{Nano-PCR with GO-AuNPs Nanocomposite}

The GO-AuNPs, including 15-nm AuNPs immobilized onto the surface of GO sheets, were included as a component of the nano-PCR reaction. To investigate whether GO-AuNPs could enhance PCR detection of FMDV, we compared DNA amplification ability between GO-AuNPs-based, and conventional real time-PCR. The optimal conditions for nano-PCR were determined by varying GO-AuNPs concentrations and AuNP sizes on the GO sheets. We designed FMDV pan-type specific primers and applied these to real-time PCR with GO-AuNPs. Optimal concentrations were determined by including $2-20 \mu \mathrm{g} / \mathrm{mL}$ of GO-AuNPs. The optimal concentration of GO-AuNPs was $\sim 10 \mu \mathrm{g} / \mathrm{mL}$ (Figure 2). Notably, $20 \mu \mathrm{g} / \mathrm{mL}$ of GO-AuNPs caused an appreciable decrease in signals. Thus, the concentration of AuNPs is crucial for enhancing PCR efficiency. GO-AuNPs can selectively bind to single-stranded DNA (ssDNA) through electrostatic interaction [23,32]. This improved PCR efficiency 
by functioning like a single-stranded DNA binding protein (SSB) that facilitates interactions between primers and templates during DNA replication in vivo. Therefore, adding $>10 \mu \mathrm{g} / \mathrm{mL}$ of GO-AuNPs impeded the PCR reaction instead of facilitating it. Despite having low affinity, excess GO-AuNPs bound not only to ssDNA, but also to double-stranded DNA (dsDNA). Therefore, $10 \mu \mathrm{g} / \mathrm{mL}$ was again the optimal GO-AuNPs concentration for nano-PCR. Thus, we included this concentration in subsequent nano-PCR experiments.
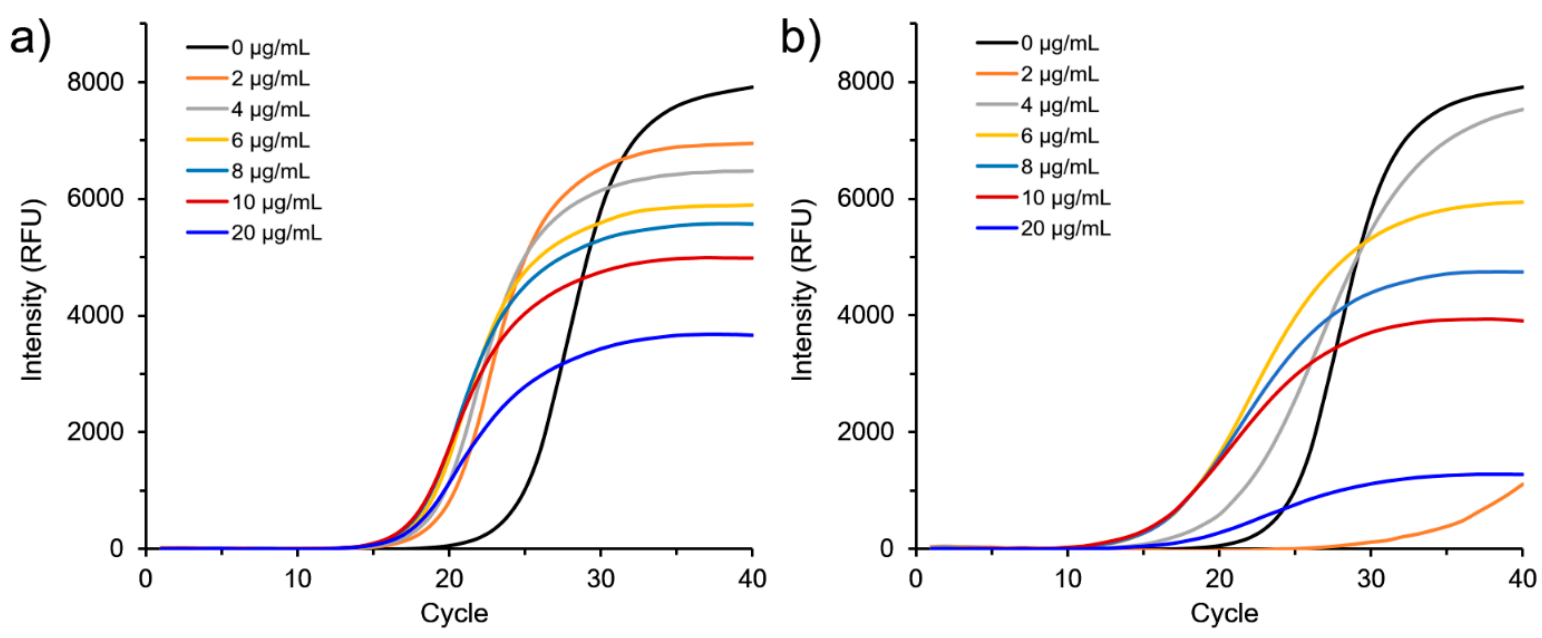

Figure 2. Effect of GO-AuNPs concentrations on nano-PCR using pan-type primers. Quantitation of FMDV O-type (a) and FMDV A-type (b) gene amplification.

We compared the performance of pristine AuNPs $(0.2-2 \mathrm{nM})$ with GO $(2-20 \mu \mathrm{g} / \mathrm{mL})$ using FMDV O-type genes. The optimal concentrations were $0.8 \mathrm{nM}$ and $4 \mu \mathrm{g} / \mathrm{mL}$, respectively (Figure S1).

We next determined the sensitivity of detecting FMDV genes. Figure 3 shows consistent signals plotted according to increasing DNA template concentrations. The estimated detection limits of FMDV $\mathrm{O}$ - and A-type genes were $100 \mathrm{fg}$ with and $100 \mathrm{pg}$ without GO-AuNPs. These results indicated that the sensitivity of real-time PCR for FMDV detection was increased by 1000 fold by adding GO-AuNPs to the PCR mixture. We directly compared the efficiency of GO-AuNPs with other nanomaterials using pristine AuNPs and GO as controls. The cycle quantitation values $(\mathrm{Cq})$ of nano-PCR using AuNPs, GO, and GO-AuNPs were plotted. The standard curves in Figure 4a show a linear relationship from $100 \mathrm{fg}$ to $10 \mathrm{ng}$ for GO and GO-AuNPs. The results of no additives and of added AuNPs ranged from $100 \mathrm{pg}$ to $10 \mathrm{ng}$ and from $1 \mathrm{pg}$ to $10 \mathrm{ng}$, respectively. That is, while the detection limits of GO-AuNPs and GO were in the order of $100 \mathrm{fg}$, those without additives and with AuNPs were in the order of $100 \mathrm{pg}$ and $1 \mathrm{pg}$, respectively. Besides, GO-AuNPs had better amplification effects than GO in terms of the cycle quantitation $(\mathrm{Cq})$ values at all points. Table 2 shows that the $\mathrm{Cq}$ values of GO-AuNPs were 4-5 cycles lower than those of GO. These findings confirmed that the effect of GO-AuNPs improved PCR performance by facilitating the powerful interactions between GO-AuNPs and PCR reagents due to the synergistic effect of GO and AuNPs [33]. Based on these results, we further confirmed the efficiency of each material by agarose gel electrophoresis (Figure $4 b$ ). Signals from bands of the PCR amplified products with GO and GO-AuNPs were more intense than those from the bands of PCR products with and without AuNPs. These results suggested that GO-AuNPs comprised the most effective enhancement material for detection of FMDV using nano-PCR. 

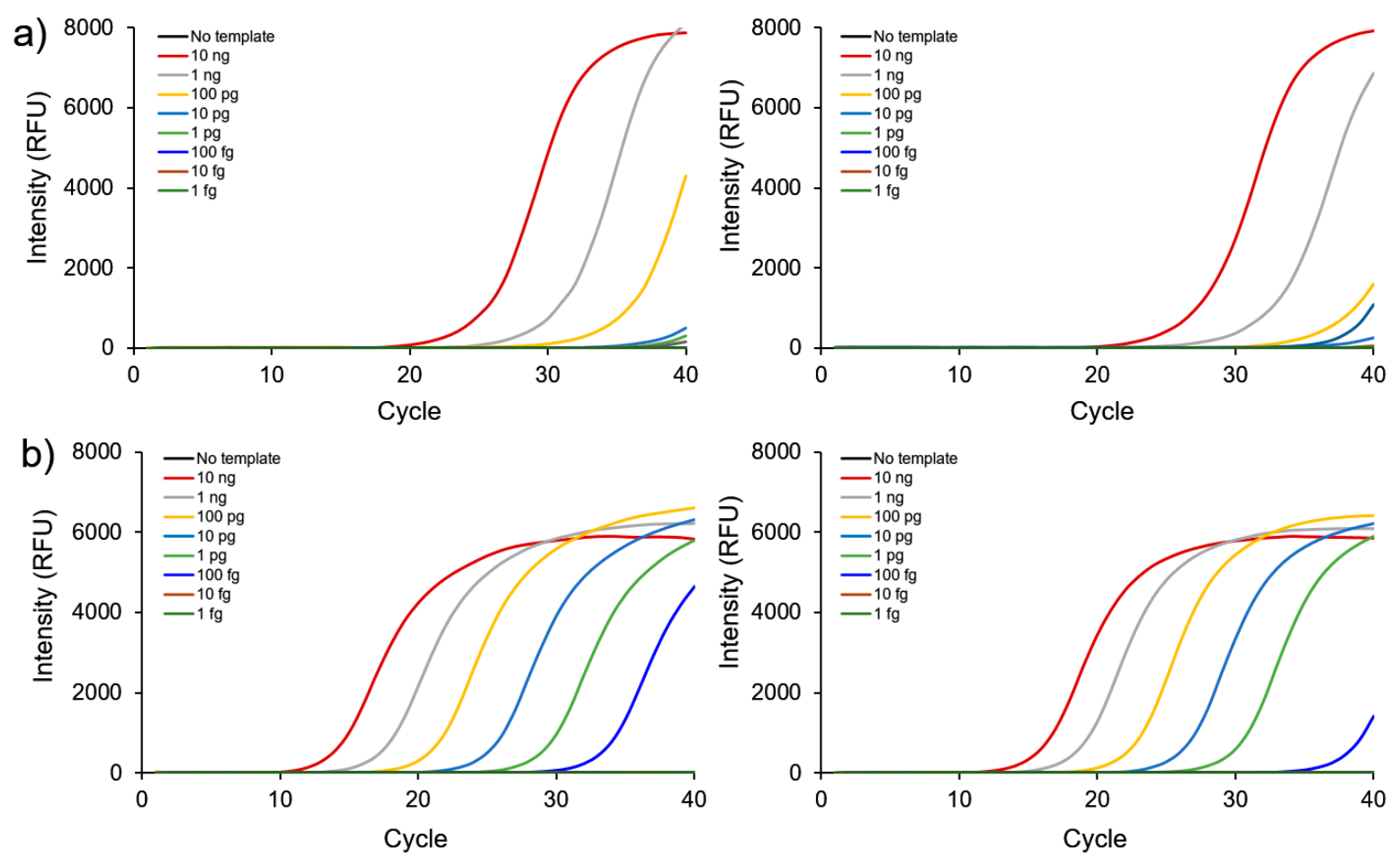

Figure 3. Effect of FMDV gene concentrations on nano-PCR using pan-type primers. Quantitation of FMDV gene amplification without (a) and with (b) GO-AuNPs. Left and right panels, O- and A-type genes, respectively.
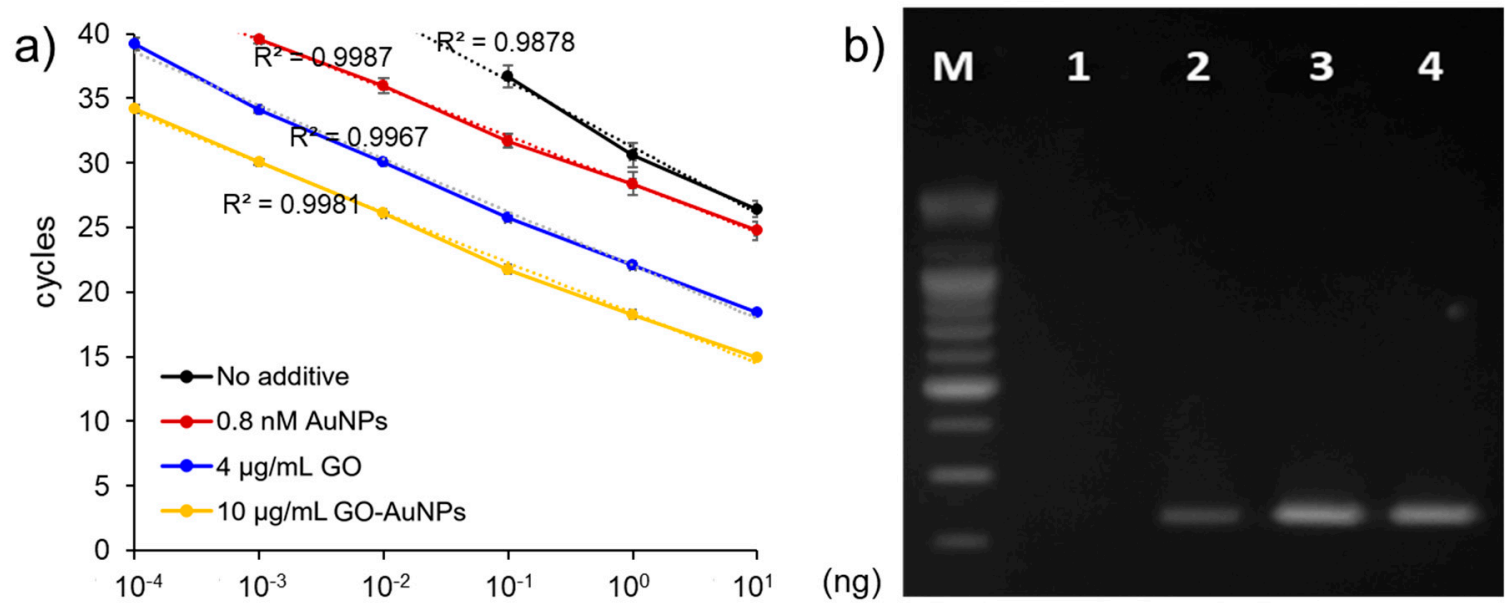

Figure 4. Comparison of additive efficiency in nano-PCR. (a) Standard curve of cycle values (Cq). (b) Size of nano-PCR product determined by agarose gel electrophoresis. Lane 1, no additives; Lanes

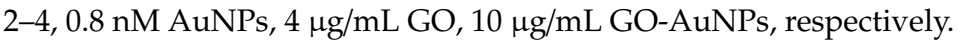


Table 2. Cycle quantitation values (Cq) compared between control and additives including AuNPs, GO, and GO-AuNPs.

\begin{tabular}{ccccc}
\hline & & \multicolumn{3}{c}{ Cycle Quantification Value $\left(\mathbf{C}_{\mathbf{q}}\right)$} \\
Concentration (ng) & No Additive & $\mathbf{0 . 8} \mathbf{~ n M ~ A u N P s}$ & $\mathbf{4} \boldsymbol{\mu g} / \mathbf{m L ~ G O}$ & $\mathbf{1 0} \boldsymbol{\mu g} / \mathbf{m L}$ GO-AuNPs \\
\hline $10^{1}$ & 26.43 & 24.74 & 18.43 & 14.92 \\
$10^{0}$ & 30.57 & 28.40 & 22.05 & 18.28 \\
$10^{-1}$ & 36.69 & 31.71 & 25.72 & 21.77 \\
$10^{-2}$ & & 35.97 & 30.07 & 26.09 \\
$10^{-3}$ & & 39.52 & 34.13 & 30.07 \\
$10^{-4}$ & & & 39.16 & 34.19 \\
\hline
\end{tabular}

\subsection{Type-Specific Detection}

Various antigens have been detected using lateral flow assays (LFA), which have also been applied in kits as rapid point-of-care tests (POCT). Two or more serotype-specific antibodies are immobilized on multiple lines (test and control lines) in one strip. However, FMDV has seven serotypes, among which serotypes $\mathrm{O}$ and $\mathrm{A}$ have recently spread worldwide, and especially in South Korea [34]. From this viewpoint, we designed a single reaction strategy to distinguish between serotypes. We also designed FMDV O- and A-type specific primers to produce different sizes of products after GO-AuNPs-based nano-PCR for FMDV type-specific detection. The specificity of nano-PCR with GO-AuNPs was evaluated using lambda DNA and E. coli genomic DNA as a control for optimization.

Figure 5 shows that both the $\mathrm{O}$ - and A-type specific primers worked specifically without amplifying other DNA templates. We also confirmed specific amplification using pan-type primers (Figure S2). We then prepared a mixture of $\mathrm{O}$ - and A-type specific primers to determine serotypes in a single reaction.
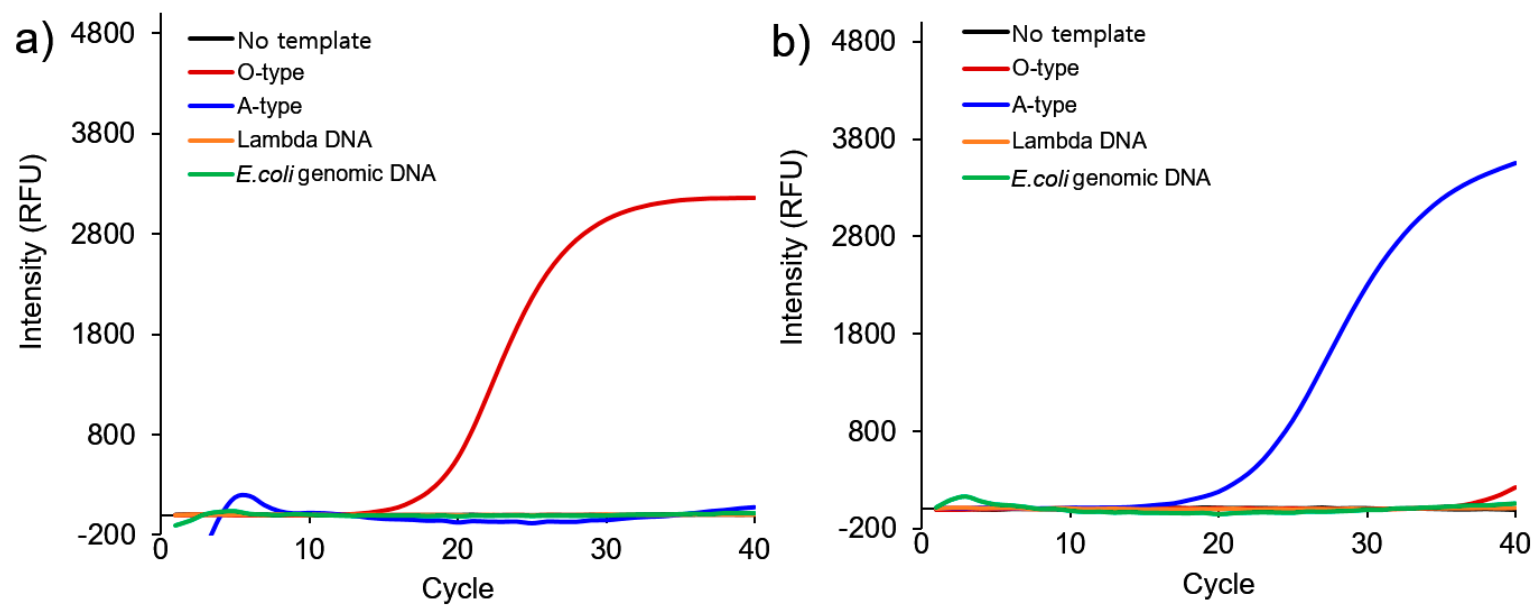

Figure 5. Specificity of nano-PCR with GO-AuNPs using O- and A-type specific primers and $10 \mathrm{ng}$ of DNA templates. (a) $\mathrm{O}$ - and (b) A type-specific primers, respectively.

Figure 6a shows fluorescent signals generated with $\mathrm{O}_{-}, \mathrm{A}$-type genes and $\mathrm{O}-$ and A-type gene primers during nano-PCR. The types were distinguished by analyzing melting curves. The estimated melting temperatures (Tm) of $\mathrm{O}$ - and A-type gene products were $83.5^{\circ} \mathrm{C}$ and $89.0{ }^{\circ} \mathrm{C}$, respectively (Figure $6 \mathrm{~b}$ ). Furthermore, melting curves of $\mathrm{O}$ - and A-type gene mixture also showed two temperature peaks representing O- and A-types. Finally, the size of products after GO-AuNPs-based nano-PCR using the primer mixture was confirmed by agarose gel electrophoresis (Figure $6 \mathrm{c}$ ). The two bands in lane 4 that resolved at 117 and 208 base pair (bp) corresponded to the O- and A-type gene products, respectively. These results indicates that our primers with GO-AuNPs are highly sensitive and specific for detecting FMDV serotypes in a single nano-PCR reaction. 

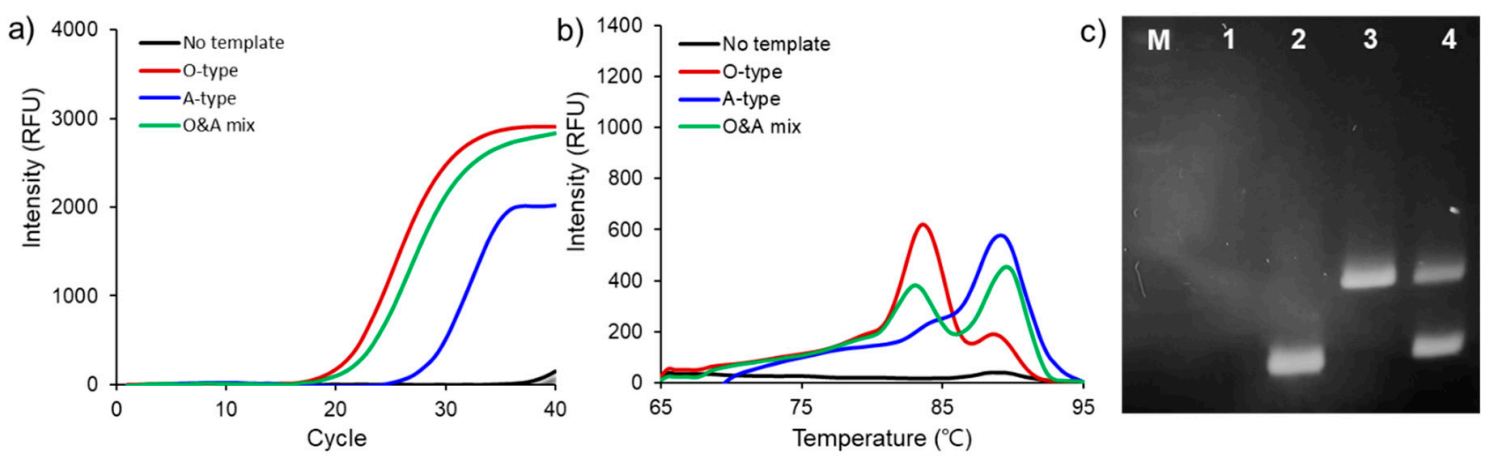

Figure 6. Real-time PCR of mixtures of O- and A-type specific primers and $10 \mathrm{ng}$ of DNA templates. (a) Quantitation of FMDV gene amplification. (b) Results of melting curve derivatives. (c) Size of nano-PCR products determined by agarose gel electrophoresis. Lane: 1, no template; lane 2, O-type genes; lane 3, A-type genes; lane 4, mixture of O- and A-type genes.

\section{Discussion}

The rapid, specific, and sensitive detection systems of FMDV have been available for years due to high transmissibility and lethality of the infection. The present main diagnostic methods of FMDV detection include RT-LAMP, RT-PCR, and LFA. The LFA is a rapid and simple immunoassay, but the sensitivity and specificity are low compared with molecular diagnostic methods. Conventional RT-LAMP and RT-PCR are widely used to base final decisions on the presence or absence of infection because amplification of the target DNA enables sensitive detection in only small amounts of specimens. However, specificity and fidelity are reduced by non-specific reactions and sample contamination, which has been a recurring issue in molecular diagnosis. Therefore, we aimed to overcome these limitations by applying nano-PCR with GO-AuNPs to reliably detect FMDV. Various nanomaterials have been applied to PCR to diagnose various diseases PCR system. The main mechanisms of enhancing PCR efficiency are selective binding to ssDNA and thermal conductivity [35]. The citrate in AuNPs can selectively bind to ssDNA rather than dsDNA via electrostatic attraction [23,32]. Additionally, GO can interact with ssDNA, primers, and polymerase through electrostatic and $\pi-\pi$ stacking interactions $[18,36]$. Owing to the unique features of both AuNPs and GO, GO-AuNPs have been proven to remarkably enhance PCR [33]. Furthermore, the good thermal conductivity of AuNPs and GO results in rapid temperature changes and improved PCR efficiency [26,37]. Therefore, GO-AuNPs have enormous utility and potential in diagnosis of FMDV.

\section{Conclusions}

We aimed to diagnose FMDV with high sensitivity and specificity using nano-PCR with GO-AuNPs. After optimizing the GO-AuNPs concentration and the AuNP size on GO sheets, the detection limits of nano-PCR for FMDV were enhanced by 1000 fold compared with PCR assays without GO-AuNPs. Based on this, we designed a strategy for serotype-specific detection in a single nano-PCR reaction and distinguished FMDV serotypes $\mathrm{O}$ and $\mathrm{A}$ by melting temperatures during real-time PCR. Among various nanomaterials that have been tested to enhance PCR efficiency, the performance GO-AuNPs in nano-PCR was superior to that of pristine AuNPs and GO. This efficient method of FMDV detection based on nano-PCR offers considerable potential for other DNA amplifications tools, such as RT-LAMP. Overall, this approach should be useful for the clinical diagnosis and monitoring of FMDV infection.

Supplementary Materials: The following are available online at http://www.mdpi.com/2079-4991/10/10/1921/s1, Figure S1: The effect of concentration of GO and AuNPs on nano-PCR using pan-type primers. Quantification of amplification of FMDV O-type genes using (a) GO and (b) AuNPs., Figure S2: Specificity of nano-PCR with GO-AuNPs using pan-type primers. $10 \mathrm{ng}$ of DNA templates used. 
Author Contributions: Conceptualization, J.-W.K. and C.-S.L.; project administration, C.-S.L.; investigation, J.-W.K., M.K., K.K.L., and K.H.C.; validation, J.-W.K.; writing-original draft of manuscript, J.-W.K.; writing-review \& editing, C.-S.L. All authors have read and agreed to the published version of the manuscript.

Funding: This work was supported by the National Research Council of Science \& Technology (NST) (No. QLT-CRC-18-01-ETRI) and the National Research Foundation (NRF-2019R1A2C1084687) grant by the Korea government (MSIT), and the KRIBB Initiative Research Program.

Conflicts of Interest: The authors declare no conflict of interest.

\section{References}

1. Knowles, N.J.; Samuel, A.R. Molecular Epidemiology of Foot-and-Mouth Disease Virus. Virus Res. 2003, 91, 65-80. [CrossRef]

2. Robson, K.J.; Harris, T.J.; Brown, F. An Assessment by Competition Hybridization of the Sequence Homology between the RNAs of the Seven Serotypes of FMDV. J. Gen. Virol. 1977, 37, 271-276. [CrossRef]

3. Kitching, R.P. Foot-and-mouth disease: Current world situation. Vaccine 1999, 17, 1772-1774. [CrossRef]

4. Alexandersen, S.; Zhang, Z.; Donaldson, A.I.; Garland, A.J. The Pathogenesis and Diagnosis of Foot-and-Mouth Disease. J. Comp. Pathol. 2003, 129, 1-36. [CrossRef]

5. Verheyden, B.; Lauwers, S.; Rombaut, B. Quantitative RT-PCR ELISA to determine the amount and ratio of positive- and negative strand viral RNA synthesis and the effect of guanidine in poliovirus infected cells. J. Pharm. Biomed. Anal. 2003, 33, 303-308. [CrossRef]

6. Reid, S.M.; Hutchings, G.H.; Ferris, N.P.; De Clercq, K. Diagnosis of foot-and-mouth disease by RT-PCR: Evaluation of primers for serotypic characterisation of viral RNA in clinical samples. J. Virol. Methods 1999, 83, 113-123. [CrossRef]

7. Lomakina, N.F.; Fallacara, F.; Pacciarini, M.; Amadori, M.; Lomakin, A.I.; Timina, A.M.; Shcherbakova, L.O.; Drygin, V.V. Application of universal primers for identification of Foot-and-Mouth Disease virus and Swine vesicular disease virus by PCR and PCR-ELISA. Arch. Virol. 2004, 149, 1155-1170. [CrossRef] [PubMed]

8. Nunez, J.I.; Blanco, E.; Hernandez, T.; Gomez-Tejedor, C.; Martin, M.J.; Dopazo, J.; Sobrino, F. A RT-PCR assay for the differential diagnosis of vesicular viral diseases of swine. J. Virol. Methods 1998, 72, 227-235. [CrossRef]

9. Fosgate, G.T.; Tavornpanich, S.; Hunter, D.; Pugh, R.; Sterle, J.A.; Schumann, K.R.; Eberling, A.J.; Beckham, T.R.; Martin, B.M.; Clarke, N.P.; et al. Diagnostic specificity of a real-time RT-PCR in cattle for foot-and-mouth disease and swine for foot-and-mouth disease and classical swine fever based on non-invasive specimen collection. Vet. Microbiol. 2008, 132, 158-164. [CrossRef]

10. Gu, C.; Zheng, C.; Shi, L.; Zhang, Q.; Li, Y.; Lu, B.; Xiong, Y.; Qu, S.; Shao, J.; Chang, H. Plus- and minus-stranded foot-and-mouth disease virus RNA quantified simultaneously using a novel real-time RT-PCR. Virus Genes 2007, 34, 289-298. [CrossRef]

11. King, D.P.; Ferris, N.P.; Shaw, A.E.; Reid, S.M.; Hutchings, G.H.; Giuffre, A.C.; Robida, J.M.; Callahan, J.D.; Nelson, W.M.; Beckham, T.R. Detection of foot-and-mouth disease virus: Comparative diagnostic sensitivity of two independent real-time reverse transcription-polymerase chain reaction assays. J. Vet. Diagn. Investig. 2006, 18, 93-97. [CrossRef] [PubMed]

12. Callahan, J.D.; Brown, F.; Osorio, F.A.; Sur, J.H.; Kramer, E.; Long, G.W.; Lubroth, J.; Ellis, S.J.; Shoulars, K.S.; Gaffney, K.L.; et al. Use of a portable real-time reverse transcriptase-polymerase chain reaction assay for rapid detection of foot-and-mouth disease virus. J. Am. Vet. Med. Assoc. 2002, 220, 1636-1642. [CrossRef] [PubMed]

13. Moss, A.; Haas, B. Comparison of the plaque test and reverse transcription nested PCR for the detection of FMDV in nasal swabs and probang samples. J. Virol. Methods 1999, 80, 59-67. [CrossRef]

14. Dukes, J.P.; King, D.P.; Alexandersen, S. Novel reverse transcription loop-mediated isothermal amplification for rapid detection of foot-and-mouth disease virus. Arch. Virol. 2006, 151, 1093-1106. [CrossRef] [PubMed] 
15. Lim, D.R.; Kim, H.R.; Park, M.J.; Chae, H.G.; Ku, B.K.; Nah, J.J.; Ryoo, S.Y.; Wee, S.H.; Park, Y.R.; Jeon, H.S.; et al. An improved reverse transcription loop-mediated isothermal amplification assay for sensitive and specific detection of serotype $\mathrm{O}$ foot-and-mouth disease virus. J. Virol. Methods 2018, 260, 6-13. [CrossRef]

16. Bath, C.; Scott, M.; Sharma, P.M.; Gurung, R.B.; Phuentshok, Y.; Pefanis, S.; Colling, A.; Singanallur Balasubramanian, N.; Firestone, S.M.; Ungvanijban, S.; et al. Further development of a reverse-transcription loop-mediated isothermal amplification (RT-LAMP) assay for the detection of foot-and-mouth disease virus and validation in the field with use of an internal positive control. Transbound. Emerg. Dis. 2020, 00, 1-13.

17. Sang, F.; Yang, Y.; Yuan, L.; Ren, J.; Zhang, Z. Development of a high-throughput real time PCR based on a hot-start alternative for pfu mediated by quantum dots. Nanoscale 2015, 7, 15852-15862. [CrossRef]

18. Jia, J.; Sun, L.; Hu, N.; Huang, G.; Weng, J. Graphene Enhances the Specificity of the Polymerase Chain Reaction. Small 2012, 8, 2011-2015. [CrossRef]

19. Vu, B.V.; Litvinov, D.; Willson, R.C. Gold Nanoparticle Effects in Polymerase Chain Reaction: Favoring of Smaller Products by Polymerase Adsorption. Anal. Chem. 2008, 80, 5462-5467. [CrossRef]

20. Kambli, P.; Kelkar-Mane, V. Nanosized $\mathrm{Fe}_{3} \mathrm{O}_{4}$ an efficient PCR yield enhancer-Comparative study with $\mathrm{Au}$, Ag nanoparticles. Colloids Surf. B Biointerfaces 2016, 141, 546-552. [CrossRef]

21. Abdul Khaliq, R.; Kafafy, R.; Salleh, H.M.; Faris, W.F. Enhancing the efficiency of polymerase chain reaction using graphene nanoflakes. Nanotechnology 2012, 23, 455106. [PubMed]

22. Bai, Y.; Cui, Y.; Paoli, G.C.; Shi, C.; Wang, D.; Shi, X. Nanoparticles Affect PCR Primarily via Surface Interactions with PCR Components: Using Amino-Modified Silica-Coated Magnetic Nanoparticles as a Main Model. ACS Appl. Mater. Interfaces 2015, 7, 13142-13153. [CrossRef] [PubMed]

23. Li, H.; Huang, J.; Lv, J.; An, H.; Zhang, X.; Zhang, Z.; Fan, C.; Hu, J. Nanoparticle PCR: Nanogold-assisted PCR with enhanced specificity. Angew. Chem. Int. Ed. Engl. 2005, 44, 5100-5103. [CrossRef]

24. Li, M.; Lin, Y.C.; Wu, C.C.; Liu, H.S. Enhancing the efficiency of a PCR using gold nanoparticles. Nucleic Acids Res. 2005, 33, e184. [CrossRef] [PubMed]

25. Lou, X.; Zhang, Y. Mechanism Studies on NanoPCR and Applications of Gold Nanoparticles in Genetic Analysis. ACS Appl. Mater. Interfaces 2013, 5, 6276-6284. [CrossRef] [PubMed]

26. Lin, Y.; Li, J.; Yao, J.; Liang, Y.; Zhang, J.; Zhou, Q.; Jiang, G. Mechanism of gold nanoparticle induced simultaneously increased PCR efficiency and specificity. Chin. Sci. Bull. 2013, 58, 4593-4601. [CrossRef]

27. Wang, J.; Cheng, Y.; Zhang, M.; Zhao, H.; Lin, P.; Yi, L.; Tong, M.; Cheng, S. Development of a nanoparticle-assisted PCR (nanoPCR) assay for detection of mink enteritis virus (MEV) and genetic characterization of the NS1 gene in four Chinese MEV strains. BMC Vet Res. 2015, 11, 1. [CrossRef]

28. Chuang, M.K.; Lin, S.W.; Chen, F.C.; Chu, C.W.; Hsu, C.S. Gold nanoparticle-decorated graphene oxides for plasmonic-enhanced polymer photovoltaic devices. Nanoscale 2014, 6, 1573-1579. [CrossRef]

29. Khalil, I.; Julkapli, N.M.; Yehye, W.A.; Basirun, W.J.; Bhargava, S.K. Graphene-Gold Nanoparticles Hybrid-Synthesis, Functionalization, and Application in a Electrochemical and Surface-Enhanced Raman Scattering Biosensor. Materials 2016, 9, 406. [CrossRef]

30. Cheng, J.; Su, X.O.; Wang, S.; Zhao, Y. Highly Sensitive Detection of Clenbuterol in Animal Urine Using Immunomagnetic Bead Treatment and Surface-Enhanced Raman Spectroscopy. Sci. Rep. 2016, 6, 32637. [CrossRef]

31. Kumari, R.; Osikoya, A.O.; Anku, W.W.; Shukla, S.K.; Govender, P.P. Hierarchically Assembled Two-Dimensional Hybrid Nanointerfaces: A Platform for Bioelectronic Applications. Electroanalysis 2018, 30, 2339-2348. [CrossRef]

32. Li, H.; Rothberg, L. Colorimetric detection of DNA sequences based on electrostatic interactions with unmodified gold nanoparticles. Proc. Natl. Acad. Sci. USA 2004, 101, 14036-14039. [CrossRef] [PubMed]

33. Jeong, H.Y.; Baek, S.H.; Chang, S.-J.; Yang, M.; Lee, S.J.; Lee, K.G.; Park, T.J. A hybrid composite of gold and graphene oxide as a PCR enhancer. RSC Adv. 2015, 5, 93117-93121. [CrossRef]

34. Park, J.H.; Lee, K.N.; Ko, Y.J.; Kim, S.M.; Lee, H.S.; Shin, Y.K.; Sohn, H.J.; Park, J.Y.; Yeh, J.Y.; Lee, Y.H.; et al. Control of Foot-and-Mouth Disease during 2010-2011 Epidemic, South Korea. Emerg. Infect. Dis. 2013, 19, 655-659. [CrossRef]

35. Sang, F.-M.; Li, X.; Liu, J. Development of Nano-Polymerase Chain Reaction and Its Application. Chin. J. Anal. Chem. 2017, 45, 1745-1753. [CrossRef] 
36. Kim, H.R.; Baek, A.; Lee, I.J.; Kim, D.E. Facilitation of Polymerase Chain Reaction with Poly(ethylene glycol)-Engrafted Graphene Oxide Analogous to a Single-Stranded-DNA Binding Protein. ACS Appl. Mater. Interfaces 2016, 8, 33521-33528. [CrossRef]

37. Balandin, A.A.; Ghosh, S.; Bao, W.; Calizo, I.; Teweldebrhan, D.; Miao, F.; Lau, C.N. Superior Thermal Conductivity of Single-Layer Graphene. Nano Lett. 2008, 8, 902-907. [CrossRef] 